\title{
The Research on Anti-dumping, Cost and Chinese Export: Based on Multilateral Resistance Term of Gravity Model
}

\author{
Rou $\mathrm{Li}^{1}$ \\ ${ }^{1}$ School of International Trade and Economics, Central University of Finance and Economics, P. R. China \\ Correspondence: Rou Li, School of International Trade and Economics, Central University of Finance and \\ Economics, Beijing 100081, P. R. China. E-mail: 2007lirou@163.com \\ Received: January 18, 2018 \\ Accepted: February 7, 2018 \\ Online Published: March 18, 2018 \\ doi:10.5539/ijbm.v13n4p210 \\ URL: https://doi.org/10.5539/ijbm.v13n4p210
}

\begin{abstract}
Using country-industry data, this study investigates the effect of anti-dumping on Chinese export via Multilateral Resistance Term of Gravity Model. Begin with the effect of anti-dumping on total export, we further investigate the mechanism between them with extensive margin and intensive margin theory in Dutt et al. (2013). We find that, anti-dumping has a statistically significant and negative effect on total export, extensive margin and intensive margin, and the increase of variable cost is the mechanism of negative effect between anti-dumping and export.
\end{abstract}

Keywords: anti-dumping, export, , cost, gravity model

\section{Introduction}

With the exit of the Trans Pacific Partnership Agreement (TPP), renegotiation the North American Free Trade Agreement (NAFTA), revision of the U.S. - Korea Free Trade Agreement, and tax reform to attract large inflows of capital, trade protection as guidelines for policy formulation has been implemented in the United States since Donald Trump was elected as the new president of the United States in 2016. As the world's biggest economic, American trade policy infers that trade protection booms again. Therefore, currently the researches on trade protection and export are very important both theoretically and practically especially for developing countries whom rely on export-oriented policy to develop economics.

We figure the trade protection taking place in China in recent years in Figure 1 (1). Figure 1 (1) shows that trade protection has been increasing in China since 2001. The number of anti-dumping cases initiated by other countries towards China is 870 with annual average 45.8 during 1995-2003, and 344 with annual average 57 during 2008-2013. In addition to anti-dumping, China also suffer from others non-tariff barriers such as countervailing investigation, sanitary and phytosanitary investigation, quantitative restrictions and so on. We followed figure the relationship between anti-dumping and export growth rate in Figure 1 (2), in which the straight line is the trends of export growth rate, the dotted line is the trends of anti-dumping. Figure 1 (2) infers the negative correlation between anti-dumping and growth rate of export.
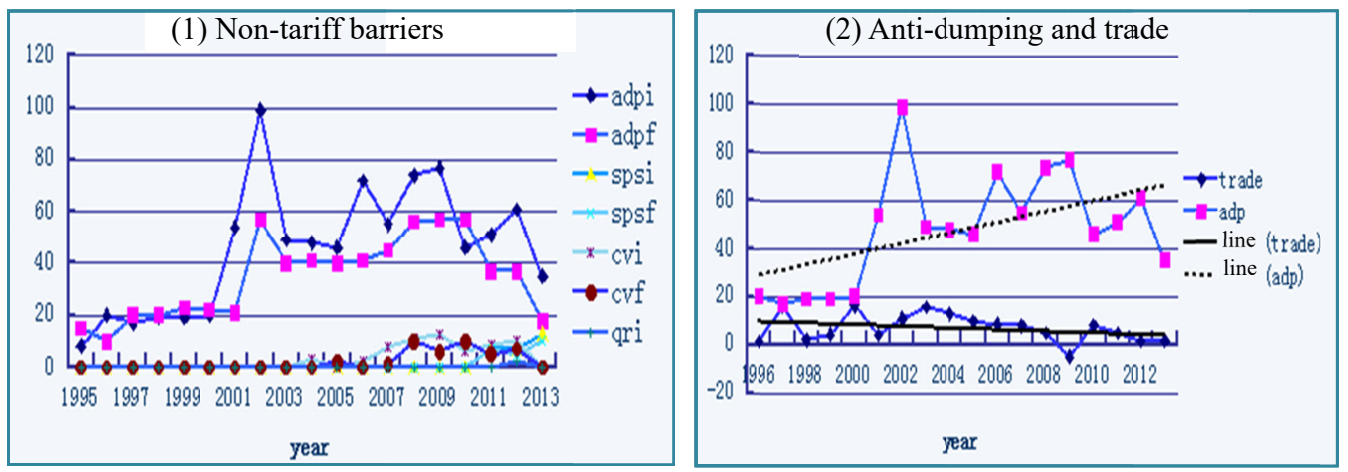

Figure 1. Trade protection and trade growth rate (1995-2013)

Note: in Figure 1 (1), adpi indicates the launched of anti-dumping investigation; adpf indicates the implement of anti-dumping investigation; spsi indicates the launched of the sanitary and phytosanitary investigation; spsf indicates the implement of sanitary and phytosanitary 
investigation; cvi indicates the launched of countervailing investigation, and cvf indicates the implement of countervailing; qri indicates the launched of quantitative restrictions. In Figure 1 (2), trade indicates the growth rate of export, ADP indicates the launched of anti-dumping investigation, the solid line indicates the linear trend of export growth rate, and the dashed line indicates the linear trend of anti-dumping.

The above analysis indicates that after China's WTO accession, Chinese exports growth rapidly, while Chinese trade frictions and barriers are also increase especially in anti-dumping investigation. Besides, the correlation between anti-dumping and export growth rate is negative.From the macro data aggregation, we cannot directly infer that the increase of anti-dumping investigation restrains growth rate of export without ruled out other factors, and cannot determine the magnitude of the restraint effect, either. Furthermore, it is unclear the specific mechanism between anti-dumping and export, thus it is necessary to consider these issues with systematically inspection.

\section{Literature Review}

There are many researches on anti-dumping and export, among which some of them infer that anti-dumping has a negative effect on export (Staiger \& Wolak, 1994; Cuyvers \& Dumont, 2004; Kongings \& Vandenbuche, 2008; Bown, 2014). As the main target of suffering from anti-dumping investigations, the studies on anti-dumping and Chinese export also infer the negative correlation between anti-dumping and export (Shen, 2008; Shen, 2012; Feng \& Xiang, 2010; Clinci, 2013; Wang et al.,2015). However, the others found that the effect of anti-dumping on export is insignificant (Bown \& McClloch, 2012; Reynolds, 2013). So currently the conclusions between anti-dumping and export are unclear, which means that it is necessary and meaningful to study the correlation between anti-dumping and export.

With the development of trade margins which can be divided into extensive margin and intensive margin (Bernard, 2003; Hummels \& Klenow, 2005), the research on trade policy and trade margin increase. Wang et al. (2014) show that anti-dumping has a negative effect on intensive margin and extensive margin, Bao and Zhu (2014) infer that technical barriers has a statistically significant and negative effect on extensive margin and intensive margin by variable cost and fixed cost. Currently the study on anti-dumping and trade margin is insufficient. In addition, eventhough the studies on fixed and variable cost with the trade margin are well established (Chaney, 2008; Dutt et al, 2008), the application and testing the trade cost, caused by trade protection, isn't enough.

Based on Dutt et al. (2013), if firm's fixed cost and variable cost decrease, the extensive margin of export increases with more enterprises entering. If the fixed cost decreases, the market share will decrease with more enterprises entering. Besides, due to the decline of fixed cost, firm with lower productivity enters the market, so the intensive margin will decrease. While if the productivitie follow Pareto distribution, the profits of exporter will increase with the variable costs decrease, however, with the increase of entering into export market, the average sales volume of each exporter decline. Therefore, the decrease of variable cost has insignificant effect on intensive margin. If the productivitie don's follow Pareto distribution, for example when upper limit firm's productivity, domestic firm's productivity will increase with the decline of variable cost and the entering of foreign firm, so the intensive margin increase. Therefore, if the changes of extensive margin and intensive margin are different, the cost of the policy will be fixed cost. If the changes of extensive margin and intensive margin are the same, or intensive margin is insignificant, the cost of policy will be variable cost. Since the firm suffering from anti-dumping probably needs to pay additional costs such as certification fee, anti-dumping investigation cost, storage cost for anti-dumping and the compensation cost for delivery of the goods, which belong to variable cost, we suppose that variable cost maybe the mechanism between anti-dumping and export. So this study further verify the mechanism from the point of variable cost.

To sum up, the possible innovations of this study are that (1) the effect of anti-dumping on export is a very important, but the conclusions of the current researches are unclear, so we need further analysis; (2) with the development of the trade margin, we need to make clear that which margin does the anti-dumping affect;(3) based on Dutt et al. (2013), we try to analysis the mechanism between anti-dumping and export from the point of trade cost by trade margins.

\section{Methodology}

\subsection{Econometric Model}

The Gravity model can better predict export behavior in theory and empirical. Therefore, based on the Multilateral Resistance Items of Gravity model (Anderson and Wincoop, 2003), this study establishes econometric model: 


$$
X_{o d j}=\frac{Y_{o} Y_{\mathrm{d}}}{Y}\left(\frac{\mathrm{t}_{o d j}}{\prod_{o j} p_{d j}}\right)^{1-\sigma}, \text { among which } \sigma>1
$$

After the logarithmic treatment of the equation (1), there are:

$$
\ln X_{\text {odj }}=a_{0}+a_{1} \ln Y_{o}+a_{2} \ln Y_{d}+a_{3} \ln t_{o d j}+a_{4} \ln \prod_{o j}+a_{5} \ln P_{d j}+\varepsilon_{i j}
$$

among which, $X_{\text {odj }}$ represents country o's export to country d in industry j; $Y_{o}$ and $Y_{d}$ represent country o and d's GDP respectively, and the sign of $a_{1}$ and $a_{2}$ is positive; $t_{\text {odj }}$ is the cost of export, and $a_{3}=1-\sigma$. Since $\sigma>1$ represents the elasticity of substitution between products, so the sign of $\mathrm{a}_{3}$ is negative with $1-\sigma<0$; $\prod_{\mathrm{oj}}$ and $\mathrm{P}_{\mathrm{dj}}$ represent whether it is easier for exporters and importers enter into the market, named Multilateral Resistance Term. If ignoring Multilateral Resistance Term, the estimation of GDP will less than the true value (Baldwin and Taglioni ,2006). Anderson and Van Wincoop (2003) treat Multilateral Resistance Term as the function of trade barriers and the corresponding elasticity, and estimate in nonlinear least squares. However, it will be more convenient by adding fixed effect to control countries' characters, we will add country fixed effect to deal with Multilateral Resistance Term as followed:

$$
\begin{aligned}
& \text { InIntrade }{ }_{o d j, t}=\beta_{0}+\beta_{1} A D P_{d j}+\beta_{2} Z_{o d, t}+\chi_{\mathrm{d}}+\mu_{j}+u_{i j t} \\
& \operatorname{lnEM}{ }_{o d j, t}=\beta_{0}+\beta_{1} A D P_{d j}+\beta_{2} Z_{o d, t}+\chi_{d}+\mu_{j}+u_{i j t} \\
& \operatorname{lnIM}{ }_{o d j, t}=\beta_{0}+\beta_{1} A D P_{d j}+\beta_{2} Z_{o d, t}+\chi_{d}+\mu_{j}+u_{i j t}
\end{aligned}
$$

Intrade $_{\text {odj,t }}$ represents country o's export to country $d$ in industry $j$ year $t ; \mathrm{EM}_{\text {odj,t }}$ represents the extensive margin of country o's export to country $d$ in industry $\mathrm{j}$ year $\mathrm{t}$; and $\mathrm{IM}_{\mathrm{odj}, \mathrm{t}}$ represents the intensive margin of country o's export to country $d$ in industry $j$ year t. Based on the method of Hummels and Klenow (2005) and Dutt et al.(2013), we calculate the extensive margin and intensive margin. Specifically, the extensive margin is $\mathrm{No}_{\mathrm{dj}}$, which represents the types of products country o's export to country $d$ in industry $j$. Intensive margin is $\bar{X}_{\text {odj }}=X_{\text {odj }} / N_{\text {odj }}$, where the $X_{\text {odj }}$ is total export from country o to country $d$ in industry $j$, so the intensive margin represents the average export of each product in industry $\mathrm{j}$.

There are three variables which represent anti-dumping ADP. The first one is whether there is anti-dumping launched by country $d$ towards country o industry $j, 1$ for yes otherwise 0 . The second one is the degree of the anti-dumping, which is the number of anti-dumping launched by country $\mathrm{d}$ towards country o industry $\mathrm{j}$ divided by total number of anti-dumping launched by the world towards country o industry $\mathrm{j}$. The third one is the number of anti-dumping, which is the number of anti-dumping launched by country $\mathrm{d}$ towards country o industry $\mathrm{j}$. This study mainly observes the first one, while the degree of anti-dumping and the quantity of anti-dumping are tested as the robustness.

$Z_{\text {od,t }}$ are control variables commonly used in the Gravity model such as the distance between two countries, the GDP per capita of the destination country, the population of the destination country, whether join WTO, whether share the common boundary, whether sign the regional trade agreement, the export country's exchange rate and destination country's tariff. $\chi_{d}$ is country's fixed effect, which controls country's specific characters, and $\mu_{j}$ is industry's fixed effect, which controls industry's specific characters.

\subsection{Data}

This study including 27 countries and regions during 1995 - 2013, in which the export data, SITC one-digit, comes from the United Nations Conference on Trade and Development UNCTAD; the anti-dumping data comes from the Bown anti-dumping database. Since the anti-dumping data is counted in HS code, so we transformed the data into the SITC code with the transformation code between HS and SITC. Besides, the data of GDP per capita and population come from United Nation Comtrade Database UNCOMTRADE, the data of exchange rate and tariff come from the World Bank, the data of Free Trade Agreement comes from WTO. In order to solve the problem of endogeneity between anti-dumping and export growth rate, this study takes the first order difference in dependent variables and takes the first order lag of independent variables (Shen, 2012). 


\section{Results}

\subsection{Basic Results}

First of all, this study investigates the effect of anti-dumping on total export in Table 1, among which we don't add the country and industry fixed effects in column (1), add the country fixed effect in column (2), and add country and industry fixed effects in column (3). Table 1 shows that the effect of anti-dumping on export is statistically significant and negative, which means that anti-dumping investigation will significantly restrain the growth rate of export. The result of this study similar with Staiger and Wolak(1994), Cuyvers and Dumont(2004), Kongings and Vandenbuche(2008),Pierce(2009)and Bown(2014).

For others control variables, the effect of per capita GDP on export is positive; the effect of population on export is positive; the effect of distance on export is negative, which consist with the prediction of traditional Gravity model (Anderson and Wincoop, 2003). In addition, the effect of WTO on export is positive, the effect of tariff on export is negative but insignificant; the effect of exchange rate on export is positive, since the rise of exchange rate will decrease export by RMB depreciation. Finally, the effect of FTA on export is positive but insignificant. Since the coefficients of the control variables almost consist with the economic analysis, the results of these regressions can be reliable.

Table 1. The effect of anti-dumping on export

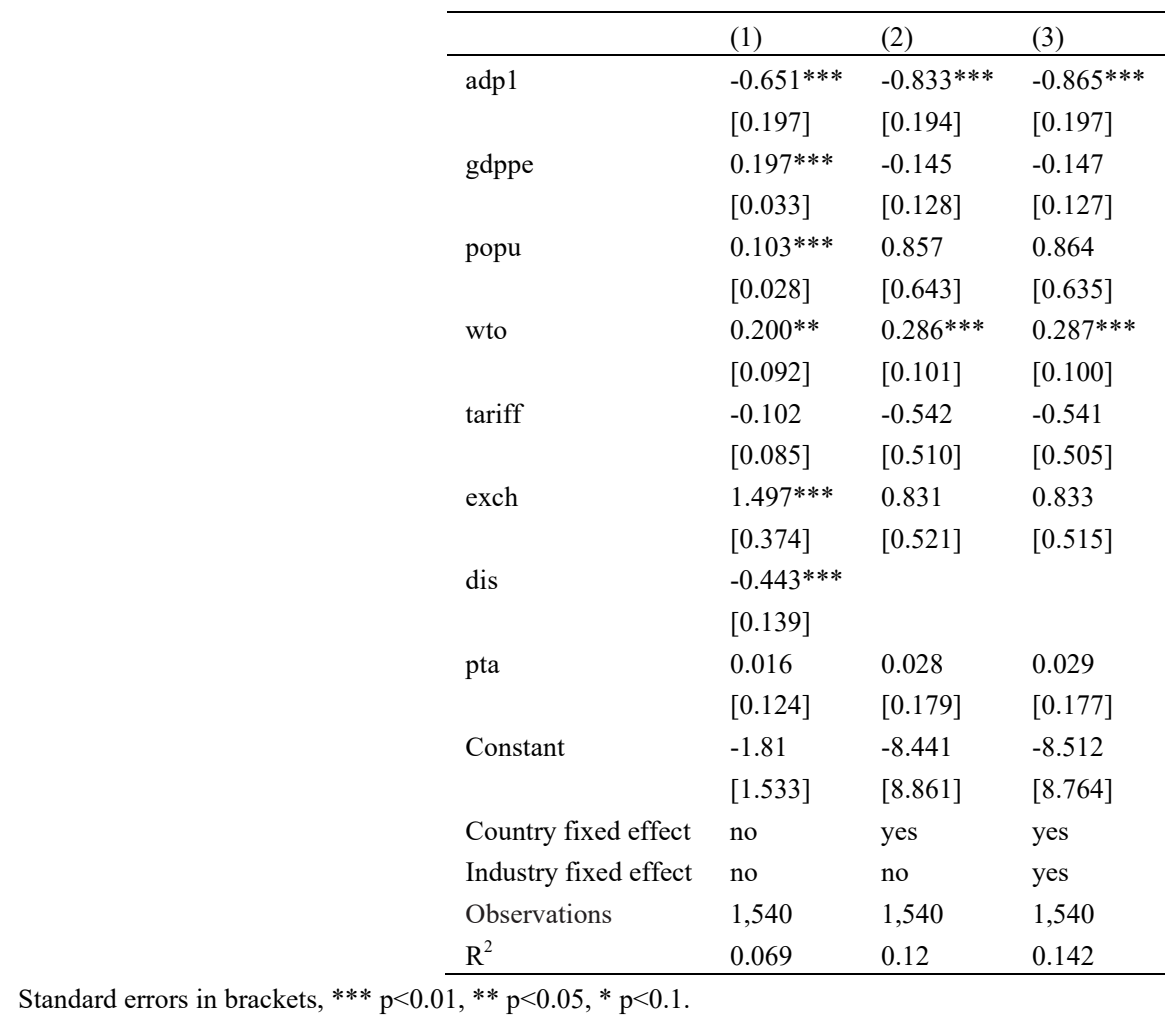

\subsection{Robustness Test}

In order to make the results more credible, we use the degree of anti-dumping and the quantity of anti-dumping to test the robustness in Table 2, among which we use the degree of anti-dumping in columns (1) - (3). We don't add country and industry fixed effects in column (1); add country fixed effect in column (2); and add country and industry fixed effects in column (3). The results of columns (1) - (3) infer that the effect of anti-dumping on export is statistically significant and negative. In addition, we use the quantity of anti-dumping in columns (4) (6), in which we don't add the country and industry fixed effects in column (4), add country fixed effect in column (5), and add country and industry fixed effects in column (6). The results of columns (4) - (6) infer that the number of anti-dumping have a statistically significant and negative effect on export. The results of the robustness tests still support the conclusions in Table 1, which means that the results of this paper are credible. 
Table 2. Robustness tests

\begin{tabular}{|c|c|c|c|c|c|c|}
\hline & $(1)$ & (2) & (3) & (4) & $(5)$ & $(6)$ \\
\hline \multirow[t]{2}{*}{ adp2 } & $-3.629 * * *$ & $-4.517 * * *$ & $-4.398 * * *$ & & & \\
\hline & {$[0.795]$} & {$[0.785]$} & {$[0.780]$} & & & \\
\hline \multirow[t]{2}{*}{ adp3 } & & & & $-0.121^{*}$ & $-0.165 * *$ & $-0.171 * * *$ \\
\hline & & & & {$[0.065]$} & {$[0.064]$} & {$[0.064]$} \\
\hline \multirow[t]{2}{*}{ gdppe } & $0.203 * * *$ & -0.141 & -0.141 & $0.192 * * *$ & -0.145 & -0.146 \\
\hline & {$[0.033]$} & {$[0.128]$} & {$[0.126]$} & {$[0.033]$} & [0.129] & {$[0.128]$} \\
\hline \multirow[t]{2}{*}{ popu } & $0.105^{* * *}$ & 1.025 & 1.015 & $0.099 * * *$ & 0.769 & 0.773 \\
\hline & {$[0.028]$} & [0.641] & {$[0.634]$} & {$[0.028]$} & {$[0.645]$} & {$[0.638]$} \\
\hline \multirow[t]{2}{*}{ wto } & $0.189^{* *}$ & $0.265^{* * *}$ & $0.265^{* * *}$ & $0.192 * *$ & $0.278 * * *$ & $0.279 * * *$ \\
\hline & {$[0.091]$} & [0.101] & {$[0.100]$} & {$[0.092]$} & {$[0.102]$} & {$[0.101]$} \\
\hline \multirow[t]{2}{*}{ tariff } & -0.101 & -0.431 & -0.435 & -0.099 & -0.576 & -0.576 \\
\hline & {$[0.085]$} & {$[0.508]$} & {$[0.503]$} & {$[0.085]$} & {$[0.512]$} & {$[0.507]$} \\
\hline \multirow[t]{2}{*}{ exch } & $1.433 * * *$ & 0.793 & 0.793 & $1.457 * * *$ & 0.771 & 0.77 \\
\hline & {$[0.373]$} & {$[0.518]$} & {$[0.513]$} & {$[0.375]$} & {$[0.523]$} & {$[0.517]$} \\
\hline \multirow[t]{2}{*}{ dis } & $-0.452 * * *$ & & & $-0.432 * * *$ & & \\
\hline & {$[0.138]$} & & & [0.139] & & \\
\hline \multirow[t]{2}{*}{ pta } & 0.012 & 0.016 & 0.016 & 0.013 & 0.019 & 0.02 \\
\hline & {$[0.124]$} & {$[0.178]$} & {$[0.176]$} & {$[0.125]$} & {$[0.180]$} & {$[0.178]$} \\
\hline \multirow[t]{2}{*}{ Constant } & -1.664 & -10.556 & -10.431 & -1.739 & -7.248 & -7.262 \\
\hline & {$[1.528]$} & [8.836] & {$[8.744]$} & [1.537] & [8.888] & [8.791] \\
\hline Country fixed effect & no & yes & yes & no & yes & yes \\
\hline Industry fixed effect & no & no & yes & no & no & yes \\
\hline Observations & 1,540 & 1,540 & 1,540 & 1,540 & 1,540 & 1,540 \\
\hline $\mathrm{R}^{2}$ & 0.075 & 0.128 & 0.149 & 0.064 & 0.113 & 0.136 \\
\hline
\end{tabular}

Standard errors in brackets, ${ }^{* * *} \mathrm{p}<0.01,{ }^{* *} \mathrm{p}<0.05,{ }^{*} \mathrm{p}<0.1$.

\section{Mechanism Tests}

\subsection{The Effect of Anti-dumping on Trade Margins}

The above studies infer that anti-dumping has a statistically significant and negative effect on export. However, which part of the trade margins contribute to the negative effect is unclear. Besides, the mechanism of the negative effect needs further verify. Therefore, this study further investigates the effect of anti-dumping on extensive margin and intensive margin, then based on Dutt et al. (2013) we analyzes the mechanism of anti-dumping by trade margin. According to Dutt et al. (2013), if the changes of extensive margin and intensive margin are opposite, anti-dumping will affect trade by increase of fixed cost. If the changes of extensive margin and intensive margin are the same, or the intensive margin is insignificant, anti-dumping will affect trade by the increase of variable cost.

Table 3. The effect of anti-dumping on extensive margin

\begin{tabular}{llll}
\hline & $(1)$ & $(2)$ & $(3)$ \\
\hline adp1 & $-0.262^{* * *}$ & $-0.315 * * *$ & $-0.330^{* * *}$ \\
& {$[0.057]$} & {$[0.057]$} & {$[0.057]$} \\
gdppe & $0.059^{* * *}$ & -0.045 & -0.045 \\
& {$[0.010]$} & {$[0.037]$} & {$[0.037]$} \\
popu & $0.028^{* * *}$ & 0.283 & 0.287 \\
& {$[0.008]$} & {$[0.187]$} & {$[0.185]$} \\
wto & -0.001 & 0.024 & 0.024 \\
& {$[0.027]$} & {$[0.029]$} & {$[0.029]$} \\
tariff & -0.035 & -0.142 & -0.142 \\
& {$[0.025]$} & {$[0.148]$} & {$[0.147]$} \\
exch & $0.193 *$ & 0.002 & 0.003 \\
& {$[0.109]$} & {$[0.152]$} & {$[0.150]$} \\
\hline
\end{tabular}




\begin{tabular}{llll}
\hline dis & $-0.138^{* * *}$ & & \\
& {$[0.040]$} & & 0.002 \\
pta & -0.007 & 0.001 & {$[0.051]$} \\
& {$[0.036]$} & {$[0.052]$} & -2.374 \\
Constant & 0.061 & -2.367 & {$[2.546]$} \\
& {$[0.445]$} & {$[2.577]$} & yes \\
Country fixed effect & no & yes & yes \\
Industry fixed effect & no & no & 1,540 \\
Observations & 1,540 & 1,540 & 0.143 \\
$\mathrm{R}^{2}$ & 0.07 & 0.118 & \\
\hline
\end{tabular}

Standard errors in brackets, ${ }^{* * *} \mathrm{p}<0.01,{ }^{* *} \mathrm{p}<0.05,{ }^{*} \mathrm{p}<0.1$.

Table 3 investigates the effect of anti-dumping on extensive margin, in which columns (1) - (3) represent the effect of anti-dumping investigation on extensive margin where we don't add the country and industry fixed effects in column (1), add country fixed effect in column (2), and add country and industry fixed effects in column (3). The results of columns (1) - (3) infer that anti-dumping investigation will significantly reduce the extensive margin, which means that anti-dumping investigation will restrain export product categories.

Followed we test the effect of anti-dumping on intensive margin in Table 4, in which the columns (1) - (3) indicate the effect of anti-dumping investigation on intensive margin, where we don't add country and industry fixed effects in column (1), add country fixed effect in column (2), and add country and industry fixed effects in column (3). The results of columns (1) - (3) show that anti-dumping investigation have a statistically significant and negative effect on intensive margin, which indicate that anti-dumping investigation significantly restrains the average export of each product.

Table 4. The effect of anti-dumping on intensive margin

\begin{tabular}{llll}
\hline & $(1)$ & $(2)$ & $(3)$ \\
\hline adp1 & $-0.356^{* *}$ & $-0.478^{* * *}$ & $-0.492^{* * *}$ \\
gdppe & {$[0.147]$} & {$[0.146]$} & {$[0.148]$} \\
& $0.129^{* * *}$ & -0.093 & -0.093 \\
popu & {$[0.025]$} & {$[0.096]$} & {$[0.095]$} \\
& $0.070^{* * *}$ & 0.572 & 0.575 \\
wto & {$[0.021]$} & {$[0.481]$} & {$[0.476]$} \\
& $0.198^{* * *}$ & $0.253^{* * *}$ & $0.254^{* * *}$ \\
tariff & {$[0.068]$} & {$[0.076]$} & {$[0.075]$} \\
& -0.062 & -0.346 & -0.346 \\
exch & {$[0.064]$} & {$[0.382]$} & {$[0.378]$} \\
& $1.271^{* * *}$ & $0.842^{* *}$ & $0.843^{* *}$ \\
dis & {$[0.279]$} & {$[0.390]$} & {$[0.386]$} \\
& $-0.286^{* * *}$ & & \\
pta & {$[0.104]$} & & 0.027 \\
Constant & 0.024 & 0.027 & {$[0.132]$} \\
Country fixed effect & {$[0.093]$} & {$[0.134]$} & -6.356 \\
\hline Industry fixed effect & -1.853 & -6.29 & {$[6.563]$} \\
\hline
\end{tabular}

Standard errors in brackets, $* * * \mathrm{p}<0.01, * * \mathrm{p}<0.05, * \mathrm{p}<0.1$. 
According to the above researches, anti-dumping has a statistically significant and negative effect on intensive margin and extensive margin. Therefore, based on Dutt et al. (2013), anti-dumping will restrains export by increase the variable cost, which means that the occurrence of anti-dumping will increase the additional costs, such as the cost of certification, additional investigation cost, storage cost as well as the compensation cost for delivery. With the increase of variable cost, the number of export categories decrease as the firm with the lower productivity cannot export. Besides, since the distribution of productivity in China doesn't follow Pareto distribution (Sun et al.,2013), the increase of variable cost has insignificant effect on intensive margin. However, export earning of each firm declines as the variable cost increases, therefore, intensive margin decline. So with the increase of variable cost, the intensive margin of export decline.

\subsection{Robustness tests of mechanism}

This study tests the robustness of the effect of anti-dumping on extensive margin with the degree of anti-dumping and the quantity of anti-dumping in columns (1) - (6) of Table 5, among which we use the degree of anti-dumping in columns (1) - (3), and use the quantity of anti-dumping in columns (4) - (6), the results of columns (1) - (6) infer that the effect of anti-dumping on the extensive margin is statistically significant and negative.

Table 5. Robustness test the effect of anti-dumping on extensive margin

\begin{tabular}{lllllll}
\hline & $(1)$ & $(2)$ & $(3)$ & $(4)$ & $(5)$ & $(6)$ \\
\hline adp2 & $-1.625^{* * *}$ & $-1.889^{* * *}$ & $-1.857^{* * *}$ & & & \\
& {$[0.229]$} & {$[0.227]$} & {$[0.225]$} & & & \\
adp3 & & & & $-0.060^{* * *}$ & $-0.073^{* * *}$ & $-0.075^{* * *}$ \\
& & & & {$[0.019]$} & {$[0.019]$} & {$[0.019]$} \\
gdppe & $0.062^{* * *}$ & -0.044 & -0.044 & $0.057^{* * *}$ & -0.046 & -0.047 \\
& {$[0.009]$} & {$[0.037]$} & {$[0.036]$} & {$[0.010]$} & {$[0.038]$} & {$[0.037]$} \\
popu & $0.029^{* * *}$ & $0.361^{*}$ & $0.359^{*}$ & $0.027^{* * *}$ & 0.257 & 0.258 \\
& {$[0.008]$} & {$[0.185]$} & {$[0.183]$} & {$[0.008]$} & {$[0.188]$} & {$[0.186]$} \\
wto & -0.006 & 0.016 & 0.016 & -0.004 & 0.022 & 0.022 \\
& {$[0.026]$} & {$[0.029]$} & {$[0.029]$} & {$[0.027]$} & {$[0.030]$} & {$[0.029]$} \\
tariff & -0.035 & -0.095 & -0.096 & -0.034 & -0.156 & -0.156 \\
& {$[0.025]$} & {$[0.147]$} & {$[0.145]$} & {$[0.025]$} & {$[0.149]$} & {$[0.147]$} \\
exch & 0.167 & -0.012 & -0.012 & $0.180^{*}$ & -0.021 & -0.021 \\
& {$[0.108]$} & {$[0.150]$} & {$[0.148]$} & {$[0.109]$} & {$[0.152]$} & {$[0.150]$} \\
dis & $-0.143^{* * *}$ & & & $-0.134^{* * *}$ & & \\
& {$[0.040]$} & & & {$[0.040]$} & & \\
pta & -0.008 & -0.003 & -0.003 & -0.008 & -0.001 & -0.001 \\
& {$[0.036]$} & {$[0.051]$} & {$[0.051]$} & {$[0.036]$} & {$[0.052]$} & {$[0.052]$} \\
Constant & 0.123 & -3.336 & -3.272 & 0.089 & -1.972 & -1.948 \\
& {$[0.441]$} & {$[2.551]$} & {$[2.522]$} & {$[0.447]$} & {$[2.588]$} & {$[2.558]$} \\
Country fixed effect & no & yes & yes & no & yes & yes \\
Industry fixed effect & no & no & yes & no & no & yes \\
Observations & 1,540 & 1,540 & 1,540 & 1,540 & 1,540 & 1,540 \\
$\mathrm{R}^{2}$ & 0.087 & 0.139 & 0.162 & 0.063 & 0.109 & 0.133 \\
\hline
\end{tabular}

Standard errors in brackets, ${ }^{* * *} \mathrm{p}<0.01,{ }^{* *} \mathrm{p}<0.05,{ }^{*} \mathrm{p}<0.1$.

Also, this study tests the robustness of the effect of anti-dumping on intensive margin by the degree of anti-dumping and the quantity of anti-dumping in columns (1)- (6) of Table 6, among which we use the degree of anti-dumping in columns (1) - (3), and use the quantity of anti-dumping in columns (4) - (5). The results of columns (1) - (6) show that anti-dumping has a statistically significant and negative effect on the intensive margin.

To sum up, the results of the robustness tests still support the conclusions in Table 3 and Table 4, which means that the results of this paper are credible. 
Table 6. Robustness test the effect of anti-dumping on extensive margin

\begin{tabular}{lllllll}
\hline & $(1)$ & $(2)$ & $(3)$ & $(4)$ & $(5)$ & $(6)$ \\
\hline adp2 & $-1.818^{* * *}$ & $-2.408^{* * *}$ & $-2.326^{* * *}$ & & & \\
& {$[0.594]$} & {$[0.590]$} & {$[0.585]$} & & & \\
adp3 & & & & -0.054 & $-0.084^{*}$ & $-0.088^{*}$ \\
& & & & {$[0.048]$} & {$[0.048]$} & {$[0.048]$} \\
gdppe & $0.132^{* * *}$ & -0.089 & -0.089 & $0.126^{* * *}$ & -0.09 & -0.091 \\
& {$[0.025]$} & {$[0.096]$} & {$[0.095]$} & {$[0.025]$} & {$[0.097]$} & {$[0.096]$} \\
popu & $0.070^{* * *}$ & 0.653 & 0.647 & $0.067 * * *$ & 0.514 & 0.517 \\
& {$[0.021]$} & {$[0.482]$} & {$[0.476]$} & {$[0.021]$} & {$[0.482]$} & {$[0.477]$} \\
wto & $0.192^{* * *}$ & $0.241^{* * *}$ & $0.241^{* * *}$ & $0.193^{* * *}$ & $0.248^{* * *}$ & $0.248^{* * *}$ \\
& {$[0.068]$} & {$[0.076]$} & {$[0.075]$} & {$[0.069]$} & {$[0.076]$} & {$[0.075]$} \\
tariff & -0.061 & -0.288 & -0.291 & -0.06 & -0.365 & -0.365 \\
& {$[0.063]$} & {$[0.382]$} & {$[0.378]$} & {$[0.064]$} & {$[0.383]$} & {$[0.379]$} \\
exch & $1.236^{* * *}$ & $0.820^{* *}$ & $0.820^{* *}$ & $1.247 * * *$ & $0.808^{* *}$ & $0.808^{* *}$ \\
& {$[0.278]$} & {$[0.389]$} & {$[0.385]$} & {$[0.279]$} & {$[0.391]$} & {$[0.387]$} \\
dis & $-0.289^{* * *}$ & & & $-0.279^{* * *}$ & & \\
& {$[0.103]$} & & & {$[0.104]$} & & \\
pta & 0.022 & 0.019 & 0.019 & 0.022 & 0.02 & 0.021 \\
& {$[0.093]$} & {$[0.134]$} & {$[0.132]$} & {$[0.093]$} & {$[0.134]$} & {$[0.133]$} \\
Constant & -1.776 & -7.334 & -7.283 & -1.813 & -5.548 & -5.592 \\
& {$[1.141]$} & {$[6.638]$} & {$[6.565]$} & {$[1.144]$} & {$[6.649]$} & {$[6.574]$} \\
Country fixed effect & no & yes & yes & no & yes & yes \\
Industry fixed effect & no & no & yes & no & no & yes \\
Observations & 1,540 & 1,540 & 1,540 & 1,540 & 1,540 & 1,540 \\
$\mathrm{R}^{2}$ & 0.087 & 0.139 & 0.162 & 0.063 & 0.109 & 0.133 \\
\hline
\end{tabular}

Standard errors in brackets, ${ }^{* * *} \mathrm{p}<0.01, * * \mathrm{p}<0.05,{ }^{*} \mathrm{p}<0.1$.

\section{Conclusions}

As Trump was elected as the new president of the United States, the trends of trade protection boom again. Therefore, currently the researches on trade protection are very important in theory and practice, especially for countries whom suffer more from anti-dumping investigations. Including 27 countries and regions during $1995-$ 2013, this study investigates the effect of anti-dumping on Chinese export via Multilateral Resistance Term of Gravity model. We found that (1) anti-dumping has a statistically significant and negative effect on export, which means that anti-dumping restrains the increase of the export in China; (2) anti-dumping has a statistically significant and negative effect on extensive margin and intensive margin, which means that the negative effect of anti-dumping not only restrains extensive margin, but also intensive margin;(3) according to Dutt et al.(2013), the effect of anti-dumping on export by increase the variable costs, such as the cost of certification, additional investigation cost, storage cost as well as the compensation cost for delivery.

The limitation of this study is the problem of endogeneity between anti-dumping and export. It is not enough even we try to solve this problem with first order lag of anti-dumping, so we need to solve this problem in others methods such as DID, IV and so on. Besides, even we applicate trade margin theory to vitrify the cost of anti-dumping, we still need to complement this research with specific variable cost in empirical research.

\section{References}

Anderson, J. E., \& Wincoop, E. V. (2003). Gravity with gravitas: a solution to the border puzzle. Boston College Working Papers in Economics, 93(1), 170-192.

Bao, Xiaohua \& Daming Zhu (2014). The impact of technical barriers to trade on the export margins: evidence from industry. China Economic Quarterly, 13(4), 1393-1414.

Baldwin, R. E., \& Taglioni, D. (2006). Gravity for dummies and dummies for gravity equations. Cepr Discussion Papers.

Bernard, A. B., Eaton, J., Jensen, J. B., \& Kortum, S. (2003). Plants and productivity in international trade. American Economic Review, 93(4), 1268-1290. 
Bown, C. P. (2014). Trade policy flexibilities and turkey: tariffs, anti-dumping, safeguards and WTO dispute settlement. World Economy, 37(2), 193-218.

Bown, C. P., \& Mcculloch, R. (2012). Antidumping and market competition: implications for emerging economies. Social Science Electronic Publishing, 1-42.

Chaney, T. (2008). Distorted gravity: the intensive and extensive margins of international trade. American Economic Review, 98(4), 1707-1721.

Clinic, \& Cristian, I. (2013). Eu's antidumping policies towards China and their implications. Academica Science Journal Economica, 2(3), 3-9.

Cuyvers, L., \& Dumont, M. (2004). The impact of anti-dumping measures of the EU against ASEAN countries on trade flows. Centre for ASEAN Studies (CAS).

Dutt, P., Mihov, I., \& Van Zandt, T. (2013). The Effect of WTO on the Extensive and the Intensive Margins of Trade. Journal of international Economics, 91(2), 204-219.

Feng,Xianzong, \& Hongjin Xiang(2010).The trade effect of European and American antidumping towards China: theoretical and empirical study. The Journal of World Economy, (3), 31-55.

Hummels, D., \& Klenow, P. J. (2005). The variety and quality of a nation's exports. The American Economic Review, 95(3), 704-723.

Konings, J., \& Vandenbussche, H. (2008). Heterogeneous responses of firms to trade protection. Journal of International Economics, 76(2), 371-383.

Reynolds, K. M. (2013). Under the cover of antidumping: Does administered protection facilitate domestic collusion?. Review of Industrial Organization, 42(4), 415-434.

Wang, X. S., Zhai, G. Y., \& Ling, F. Q. (2015). The research on inhibitory effect of anti-dumping on China's exports. The Journal of World Economy, (5), 36-58.

Wang, X. S., Shi, B. Z., Xie, S. X., \& Zhao, C. M. (2014). How do trade barriers affect dual margins of China's export growth? Economic Research Journal, 49(11), 58-71.

Shen, G. B. (2008). Antidumping and US-China bilateral intra-industry rade: an empirical analysus. Word Economy Studies, (3), 48-55

Shen, G. B. (2012). Dominant comparative advantage and the trade effect of American anti-dumping on Chinese products. The Journal of World Economy, (12), 62-82.

Staiger, R. W., \& Wolak, F. A. (1994). Measuring industry specific protection: antidumping in the United States. National Bureau of Economic Research (No. w4696).

Sun, C., Tian, G., \& Zhang, T. (2013). An application of the Melitz model to Chinese firms. Review of Development Economics, 17(3), 494-509.

\section{Copyrights}

Copyright for this article is retained by the author(s), with first publication rights granted to the journal.

This is an open-access article distributed under the terms and conditions of the Creative Commons Attribution license (http://creativecommons.org/licenses/by/4.0/). 